\title{
A TERMÉSZET- ÉS A TÁRSADALOMFÖLDRAJZOS GONDOLKODÁS KOMPLEX FEJLESZTÉSI LEHETŐSÉGEI
}

Possibilities of the complex development of physical and human geographical thinking

\author{
DARABOS KATA KA, $^{a}$ - GERLANG VIVIEN ${ }^{a, c}$ \\ ${ }^{a}$ ELTE TTK FFI Földrajz szakmódszertani csoport \\ bdarabos.kata.95@gmail.com, cherlang.vivien@gmail.com
}

\section{ABSTRACT}

Being a teacher isn't just about education, it's about so much more. Geography is a very complex subject. In addition to the transfer of knowledge, our task is also to develop our students. Competence is a term often used nowadays, but it is in several cases not well interpreted, and it is confused with other terms. Competence means proficiency in something. The three components of competence- development are the development of knowledge, skills and attitudes, as a result of wich the skills are created. Since the early 2000 's, competences has also been included in the national core curriculum, wich are referred to as „key-competencies”. Among the key competences, we present „thinking skills" in detail.

Defining the concept of thinking is not an easy task. Defining thinking skills, or cognitive competence is also complicated, and the situation is even more complicated due to the special nature of geography. Therefore, we examined the evolution of the characteristics of the subjest of geography, with special regard to the separation of physical geography and social geography. As with all subjects, the main goal of teaching geography is to educate young people who are independent, creative, recognize connections and think systemically. The goal is to teach them so, that after graduating from school, students will be able to see the world in a complex way.

Textbook is the most widely available teaching tool. Therefore, we examined the possibilities of the textbook provides for the joint development of physical geography and socio-geography thinking, thus for the developments a complex approach. In our research, we focused on the topic of the atmosphere, because it offers many oppurtunities for complex development.

Keywords: cognition, reasoning, thinking skills, general intelligence, cognitive competence, geography, education, textbook

\section{BEVEZETÉS}

Tanárnak lenni nem csupán a szaktárgyunk oktatását és a tanulók nevelését jelenti, hanem annál sokkal többet. Az ismeretek átadásán keresztül, azzal párhuzamosan fontos 
feladatunk a készség- és kompetenciafejlesztés is annak érdekében, hogy a jövő nemzedéke olyan képességekre tegyen szert, amelyek segítségével felnőttként boldogulni tud majd. Manapság gyakran használt kifejezések a készség, a képesség és a kompetencia, azonban ezek pontos jelentése kevéssé ismert, leginkább egymás szinonimájaként tekintenek rájuk. A kompetenciafejlesztés a három fö összetevő, az ismeretek, a készségek és az attitűdök kialakítására, fokozatos fejlesztésére irányul. A kompetencia ilyen szemléletű megközelítése, valamint az ehhez kapcsolódó kompetenciamodellek angolszász gyökerekhez nyúlnak vissza, de a 2000 -es évek eleje óta a hazai nemzeti alaptantervek is ezt a felfogást követik. Ennek következtében az alaptanterv különböző kulcskompetenciákat határoz meg, amelyek közül a továbbiakban a gondolkodási képesség kerül részletesebb tárgyalásra tanulmányunkban.

A gondolkodás fogalma és a gondolkodási képességek egy igen összetett és több oldalról megközelíthető témakör, ami a földrajztanítás-tanulás folyamatában speciálisan jelenik meg a tantárgy kettős jellege miatt. Ebből adódóan a gondolkodás és a gondolkodási képesség általános bemutatása után szükséges kitérnünk a természettudományos és a társadalomtudományos gondolkodás jellemzőire, hasonlóságaira és különbségeire egyaránt. Ennek megértéséhez megvizsgáljuk a földrajz tantárgy jellemzőit, különös tekintettel a természet- és a társadalomföldrajzi tartalmak elkülönülésére, különbségeire.

Mint minden tantárgy, a földrajz tanítása során is kiemelt cél az önálló, a kreatív, a különböző forrásokat kritikusan értelmező, az összefüggéseket felismerő és rendszerben gondolkodó fiatalok nevelése, akik az iskolapadból kikerülve képesek komplexen szemlélni a világ folyamatait, jelenségeit. Mivel a tankönyv a legszélesebb körben elérhetö taneszköz, fontosnak tartjuk, hogy megvizsgáljuk a komplex természet- és társadalomtudományos gondolkodás szempontjából, elsősorban arra keresve a választ, hogy milyen lehetőségeket kínál a kétféle gondolkodásmód fejlesztésére, és mennyiben tud hozzájárulni a kettőt ötvöző komplex szemléletmód kialakulásához. Kutatásunk során a légkör - mint az egyik legösszetettebb rendszer - földrajzának tanítására koncentrálunk, mert tartalmából adódóan különösen sok lehetőséget nyújt a természet- és társadalomtudományos gondolkodás együttes erősítésére.

\section{GONDOLKODÁS ÉS GONDOLKODÁSI KÉPESSÉG}

A gondolkodási képesség definiálásához elengedhetetlen a gondolkodás fogalmának meghatározása, ami nem egyszerü feladat, tekintettel arra, hogy többféle megközelítése is van. A gondolkodás, illetve a gondolkodási képesség kifejezések helyett több értelemben használt és azonos kifejezéssel találkozhatunk a hazai és külföldi szakirodalmakban. A 
hazai munkákban a megismerés, a szellemi képességek, az értelmi képességek, az intelligencia, az információfeldolgozás, a kompetencia mind-mind a gondolkodási képesség, illetve maga a gondolkodás folyamatára utalnak. Az angol nyelvben a thinking, a cognition, a reasoning szavak töltik be ezt a funkciót. A gondolkodási kompetenciára külön kifejezéseket használunk, így a thinking skills, a general intelligence, a cognitive competence szókapcsolatok jelennek meg a legtöbb esetben, de fontos megjegyezni, hogy sokszor ezen fogalmak tartalma nem pontosan fedi egymást (CsApó B. 2003). Az egyes elméletek számos, értelmében egymással többnyire nem, vagy csak részben azonos kifejezést alkalmaznak, mégis a témával foglalkozó kutatók többsége egyetért abban, hogy a gondolkodás és a gondolkodási képesség háttere a pszichológia területén keresendö, azon belül is maga a gondolkodás nagyon szoros összefüggésben van az intelligencia fogalmával (BüHNER, M. et al. 2008).

A pszichológiai kutatások a 20. században kezdtek el azzal foglalkozni, hogy miben is áll az emberi értelem lényege. Három nagy irányzat alakult ki, amelyek tudományos eredményeire ma is támaszkodunk a gondolkodási képesség vizsgálatakor: a pszichometria, a Piaget-iskola, valamint a kognitív pszichológia (CsAPó B. 2003).

A pszichometria úttörőnek tekinthető abban, hogy bevezette a mérést a pszichológia tudományába, a matematika és a statisztika módszereit felhasználva igyekezett definiálni az emberi értelem jelentését és megpróbálta mérhetővé tenni az intelligenciát. Emellett célja volt a képességek szerkezetének feltárása faktoranalízis segítségével (Rózsa S. - Hevesi K. 2006). A pszichometria ugyan sok újdonságot hozott a gondolkodás és a gondolkodási képesség kutatásában, azonban ez a paradigma semmit nem mond arról, hogy lehet-e fejleszteni a gondolkodást (CsAPó B. 2003). Ezzel szemben a francia pszichológus, ismerettankutató JEAN PIAGET (1993) nevéhez füződő elmélet megértéséhez nem volt szükség matematikai felkészültségre. Lényege, hogy az emberi fejlődés tulajdonképpen adaptáció a környezethez, aminek két fő formája az asszimiláció és az akkomodáció. Az asszimiláció során a környezetből származó információkat beépítjük a már meglévő tudásunk rendszerébe (sémába), majd, ha ezek a sémák már nem alkalmasak az új információk befogadására, akkor átrendeződés, azaz akkomodáció történik és új sémák alakulnak ki. PIAGET a gondolkodási képesség kialakulásának négy fázisát különböztette meg annak alapján, hogy milyen gondolkodási müveletet képesek elvégezni a gyerekek egy-egy fejlödési periódusban: az érzékszervi-mozgásos fázis, a müvelet előtti szakasz, a konkrét műveletek stádiuma és a müveleti szakasz (PiAget, J. - INHELDER, B. 1999). Nem úgy gondolt a tudásra, mint egy kész rendszerre, hanem egy olyan struktúraként kezelte, amelyet külső információk felvételével el lehet sajátítani, fejleszthető, ráadásul a tudást maga a személy hozza létre (konstruálja), ezért munkásságának esszenciáját szokás konstruktivista elméletnek is nevezni (CsAPó B. 2003). Piaget elmélete nehezen összeegyeztethető az előtte egyeduralkodó pszichometriai 
irányzattal, mégis van kapcsolat a két gondolkodásmód között. Tudásunk a környezetből és az azzal való interakciókból származik, a környezet rendje pedig - és így a gondolkodás struktúrája is - matematikailag leírható (PIAGET, J. - INHELDER, B. 1967).

Piaget elmélete még ma is a gondolkodási képesség fejlesztésének kiindulópontja, és az ö kutatásait vették alapul a harmadik irányzat, a kognitív pszichológia képviselői is, akik az emberi megismerést információfeldolgozásként írják le. Céljuk a megismeréssel kapcsolatos ismeretek rendszerének kialakítása. Kísérleteik eredményeként azt a következtetést vonták le, hogy a problémákat többnyire nem szerkezetük alapján oldjuk meg, hanem inkább az jellemzö, hogy gondolkodási sémáink tartalomspecifikusak (WASON, P. C. 1968). A kognitív pszichológia nemcsak a gondolkodással, hanem a kompetencia, a szakértelem fogalmakkal is foglalkozott, képviselői memóriavizsgálatokat végeztek. A kutatások eredményei arra engedtek következtetni, hogy a gondolkodás, a gondolkodási képesség fejleszthetö (NAGY J. 2003).

A gondolkodás és a gondolkodási képesség fogalma nemcsak pszichológiai, hanem pedagógiai szempontból is vizsgálható. A legszélesebb körben elterjedt modell az ún. Bloom-taxonómia, ami az amerikai oktatáspszichológus nevéhez füződik. Eszerint a gondolkodásnak több szintje van, amelyek egymásra épülve alakítják ki a gondolkodási képességet. BцоOм összesen hat rétegét különíti el a gondolkodásnak. Az első és legalapvetőbb a tények ismerete, az emlékezet és az elraktározás készsége, a második a felfogás, a megértés, vagyis a tények értelmezése, majd az alkalmazás, azaz a tények felhasználása. Ezeket a gondolkodás alacsonyabb szintjeinek nevezi. A következö három szakasz az elemzés (analízis), a tények részekre bontása, az összegzés (szintézis), valami új létrehozása a tényekből és az értékelés, vagyis az ismeret megítélése, felmérése. Ezek a gondolkodás magasabb szintjeit alkotják (BLOOM, B. 1965). A rendszert a pszichológus és munkatársai 2001-ben frissítették, aminek következtében újragondolták a szintézis és az értékelés helyét, a szintézist alkotásnak nevezték át (ANDERSON, L. W. - KRATHWOHL, D. R. et al. 2001, 1. ábra). BLoom modellje máig nagy hatással van a pedagógiai irányzatokra és a tanításmódszertani elméletekre egyaránt.

Jelenleg a gondolkodást alapkészségnek tekintjük, aminek három, egymásra épülő szintje különíthető el. Az első lépcsőfok a kreatív gondolkodás, amit a kritikai gondolkodás követ. Ezekre épül a gondolkodás legmagasabb szintje, az úgynevezett problémamegoldó gondolkodás. A modell szerint akkor léphet valaki a gondolkodás magasabb szintjére, ha a korábbi alapjait már elsajátította. A Bloom-taxonómiára építő elmélet napjainkban a szakmetodikában általánosan elfogadott és alkalmazott (MAKÁDI M. 2015, 2. ábra).

A gondolkodás folyamatának leírására számos definíció született, amelyek közül a továbbiakban JONATHAN BARON (1988) amerikai pszichológus meghatározását vesszük 
alapul. Az ő felfogása szerint a gondolkodás egy olyan pszichológiai folyamatokra épülő művelet, amely során elvont vagy szemléletes ismereteket használunk problémamegoldásra vagy új ismeretek szerzésére. Ugyan már az 1978-as tantervben megjelent hazánkban az általános igény a gyermekek önálló tevékenykedtetésére, gondolkodtatására, és nagy súlyt fektettek a gondolkodásfejlesztésre, azonban mindez határozottan és elemeiben megfogalmazott alapkövetelmény csak a 2007-es Nemzeti alaptanterv bevezetése után lett. Abban ugyanis már szerepelt a kompetenciafejlesztés fogalma, és az Európai Unió által kidolgozott kulcskompetenciákat is beemelték az oktatási rendszerbe. Ennek értelmében a gondolkodási képesség olyan kompetencia lett, aminek fejlesztése a tantervi célkitűzések szerves részét képezi. A gondolkodási képesség értelmezésében a 2020-ig érvényben lévő szabályozók által is alkalmazott pedagógiai megközelítés alapján a gondolkodási képesség az intellektuális kompetenciák közé sorolható, a kognitív kulcskompetenciák része (NAGY J. 2000). Ez azonban a 2020-tól életbe lépett Nemzeti alaptantervben már külön kulcskompetenciaként szerepel matematikai, gondolkodási kompetencia néven.

\section{TERMÉSZET- ÉS TÁRSADALOMTUDOMÁNYOS GONDOLKODÁS}

A gondolkodás és a gondolkodási képesség már régóta ismert, kutatott folyamatok, amelyek meghatározása rendkívül összetett, lévén hogy több szemszögből is 
megközelíthetők. A vizsgálatok nézöpontja ugyan különböző, azonban céljuk közös: a gondolkodási folyamat megismerése és a készségfejlesztést befolyásoló tényezők feltárása.

Elmondható, hogy a gondolkodás folyamata, jellemzői nem egységesek, minden tudományágon belül megvannak a jellemző vonásai és módszerei. Mivel minden tudományterület más és más gondolkodási módszerekkel, jellegzetességekkel rendelkezik, így többfajta gondolkodásmód létezik, amelyek kisebb-nagyobb mértékben eltérnek egymástól. Azonban az iskola és a tudomány nem azonos, így az iskolában még bonyolultabb a helyzet. A földrajz tantárgy speciálisnak tekinthető abból a megközelítésből, hogy két tudományág ismereteit ötvözi, abban a természet- és társadalomtudományi ismeretek egyaránt képviseltetik magukat. Ennek következtében a földrajz tantárgyban a két tudománycsoportra jellemző gondolkodási módszerek egyaránt felfedezhetők (MAKÁdi M. 2015). A természet- és társadalomtudományok, így a természet- és a társadalomföldrajz is alapvetően eltérő gondolkodási stratégiákat igényelnek, mégis, alkalmazásuknak és fejlesztésüknek egymással párhuzamosan, egymásba fonódóan kell történnie a földrajzórákon (1. táblázat).

Ahogyan az 1. táblázatban is látható, a természettudományos gondolkodás jellegzetességei közé tartozik a mintázatok készítése a rész-egész és a hasonlóságok-különbségek elemzésével, az előrejelzés és a következtetések igazolása, valamint az ok-okozati összefüggések feltárása. Ezzel szemben a társadalomtudományos gondolkodás alapja az elképzelések, a modellek megalkotásának képessége. Látható, hogy a két tudományterületen jellemzően alkalmazott gondolkodás eltérő, azonban vannak közös jellegzetességeik. Mind a társadalomföldrajzi, mind a természetföldrajzi gondolkodásra jellemző többféle szempont egyidejü alkalmazása, a problémamegoldás és a megoldások értékelése, valamint a mérlegelés érvek és ellenérvek alapján (MAKÁdI M. 2015). Ugyan a

\begin{tabular}{|c|c|}
\hline Természettudományos gondolkodás & Társadalomtudományos gondolkodás \\
\hline $\begin{array}{l}\text { Analizáló gondolkodás, szempontrendszerek } \\
\text { alapján történő gondolkodás, ismeretek szinte- } \\
\text { tizálása }\end{array}$ & Többféle szempont egyidejü alkalmazása \\
\hline \multicolumn{2}{|c|}{ Problémamegoldás } \\
\hline $\begin{array}{l}\text { Ok-okozati összefüggések meglátása, előzetes } \\
\text { hipotézis alkotása, igazolása }\end{array}$ & Hipotézis működőképességének vizsgálata \\
\hline Rész-egész kapcsolatok értelmezése & Hálózatokban való gondolkodás \\
\hline $\begin{array}{l}\text { Válaszok alapján előrejelzések adása, prog- } \\
\text { nosztizálás }\end{array}$ & Érvek, ellenérvek alapján döntéshozatal \\
\hline Cél a minél egzaktabb eredmény elérése & Cél a gondolkodási folyamat végigjárása \\
\hline \multicolumn{2}{|c|}{ A megszerzett információk, tudás alkalmazása } \\
\hline
\end{tabular}

1. táblázat. A természet-és társadalomtudományos gondolkodás jellemzői a földrajztanításban (MAKÁDI M. 2015 alapján) 
kétfajta gondolkodásmód eltér egymástól, de számos közös vonásuknak köszönhetően közös fejlesztésük nemcsak lehetséges, hanem szükséges is, hiszen a földrajz tantárgy integrált jellege éppen ezt igényli.

\section{A FÖLDRAJZTUDOMÁNY A TERMÉSZET- ÉS A TÁRSADALOMTUDOMÁNYOK METSZETÉBEN}

A 18. században a társadalomtudományok és a természettudományok kutatásmódszertana még nagyon hasonló volt, a terepi megfigyelések, leíró jellegű vizsgálatok mindkét területre jellemzők voltak. A 19. század második felében a műszeres vizsgálatok szerepének felértékelődése azonban egyfajta eltávolodást eredményezett a két tudományterület között. Egyre több ember dolgozott együtt, munkacsoportok alakultak ki, nőtt az anyagigény és a költség a természettudományokban, míg a társadalomtudományok kutatási módszertana nem változott (KuHN, T. S. 2000). A világháborúk a tudományos kutatásban is átalakulást eredményeztek. A második világháborús vereséget követően a németországi földrajztudomány korábbi fejlődése megtorpant, ugyanakkor az Amerikai Egyesült Államokban, valamint a Szovjetunióban különösen a matematikához és a fizikához szorosabban kapcsolódó természetföldrajz szerepe felértékelödött (РRовÁLD F. 1999). A hidegháború tovább erősítette a földrajztudomány e két nagy területének eltávolodását, hiszen a matematika, a fizika, valamint a kémia került előtérbe, aminek következtében egyre többet költöttek alkalmazott kutatásokra és labormunkára, amikhez új szereplők, vállalatok is csatlakoztak. A társadalomtudományokra azonban továbbra sem volt jellemző a labormunka és a matematikai módszerek alkalmazása (Livingstone, D. N. 2009).

A legtöbb európai országban úgy vélekedtek, hogy a földrajztudomány integráló jellegű, és épp az a különlegessége, egyben hatékonyságának a kulcsa, hogy két különböző nagy tudományterület alkot benne egységet, így azok különválasztása nem tanácsos. Ezzel szemben a Szovjetunióban, Hollandiában, Svédországban és hazánkban is az úgynevezett dualista felfogás térhódítása volt megfigyelhető, a földrajztudomány egyre inkább két részre oszlott, a természetföldrajzra és gazdaságföldrajzra (РrовÁLd F. 1999). A kettéválást tovább erősítette, hogy a természet- és társadalomtudományok publikációs jellegzetességei eltértek egymástól. Míg a 18. században a tudományos hátteret egységesen a filozófia (teológia) jelentette, addig 19. században a természettudományokban megjelent a pozitivizmus, mint tudománytörténeti háttér. A 20. században a kvantitatív forradalom hatására a kutatások során mindent elkezdtek számszerűsíteni, modellezni, ami viszont közelebb hozta egymáshoz a két tudományágat. Azonban az 1970-es években újabb eltávolodás következett be, a 
társadalomtudomány szakított a kvantitatív forradalommal és olyan új elméleteket kezdett bevonni a kutatásba, mint a feminizmus és a humanizmus (Livingstone, D. N. 1992). Úgy tűnt tehát, hogy a földrajztudomány a legtöbb helyen két részre szakadt, nemcsak módszertanilag vagy a publikációk terén, hanem az intézményrendszerben is, így több esetben az egyetemeken külön természet- és társadalomföldrajzi tanszékek alakultak (SHAPIN, S. 1998).

A földrajztudomány természettudományi és társadalomtudományi alapú két ága az elmúlt évtizedekben érzékelhetően eltávolodott egymástól. Az iskolában ugyan a földrajz tantárgy keretein belül elvileg mindkét terület ismeretanyaga és gondolkodásmódja szerepet kap, mégis sokszor nincs valódi kapcsolat közöttük, sőt, egymástól mesterségesen elválasztva nem is azonos évfolyamon tanítjuk azokat. Természetesen vannak olyan témák, amikkel mindkét tudományág egyaránt foglalkozik. Ezek szerepe egyre jobban felértékelödik, hiszen a közös fejlesztés segíthet kialakítani a világ megismeréséhez szükséges komplex szemléletmódot. Ilyen összetett, több oldalról megközelíthető témakörök például az éghajlatváltozás, a légkör földrajza, a globális kihívások vagy a talajpusztulás (ViLEs, H. 2005).

\section{KOMPLEX SZEMLÉLETMÓD}

A történelmi áttekintésből látható, hogy a természetföldrajz és a társadalomföldrajz mint tudományterületek eltérő fejlődési utat jártak be. Míg a természetföldrajz elsődleges célkitűzése Földünk természeti jelenségeinek a megismerése, törvényeinek feltárása, addig a társadalomföldrajzi tartalmak a társadalmi-gazdasági folyamatokról nyújtanak információkat. A különböző megközelítés ellenére a végső cél minden esetben ugyanaz: Földünk mint környezetünk minél átfogóbb megismerése, folyamatainak és kölcsönhatásainak megértése, az ember földi rendszerekben elfoglalt helyének feltérképezése. Ez a kettősség az iskolai oktatási-nevelési munkára is hatással van, hiszen a természettudományos és a társadalomtudományos gondolkodás különbözősége miatt azok fejlesztése sem történhet azonos módon. Ugyan az egyes földrajzi tartalmak eltérő megközelítései különböző eszközöket, gondolkodásmódot igényelnek és ezáltal eltérő fejlődési utat eredményeznek, mégsem zárják ki egymást, sőt egyenesen feltételezi egyik a másikat.

A tanítási-tanulási folyamat során fontos szempont, hogy olyan tanulókat neveljünk, akik értik a világ folyamatait, képesek önállóan gondolkodni és véleményt formálni, döntést hozni, rendszerben látni világunkat. Ehhez olyan komplex gondolkodásmódra van szükség, amit a csak természettudományos vagy a csak társadalomtudományos tudás önmagában nem képes megadni, nélkülözhetetlen mindkettő fejlesztése ahhoz, 
hogy gondolkodó, kreatív, önálló problémamegoldásra képes fiatalok kerüljenek ki az iskolából. Ennek érdekében elengedhetetlen, hogy az egyszerủ ismeretátadás helyett a világot a maga komplexitásában ismertessük meg a tanulókkal, aminek része az ok-okozati viszonyok feltárása, az összefüggések értelmezése, a rész-egész kapcsolatok felismertetése és azok elhelyezése a földrajzi folyamatokban. Ez akkor lehet igazán sikeres, ha a természet- és társadalomföldrajzra nem különálló területekként tekintünk, hanem törekszünk - sajátos vonásaikat felhasználva - egyszerre fejleszteni a kétfajta gondolkodásmódot a komplex szemléletmód kialakítása érdekében.

\section{VAN-E KOMPLEX SZEMLÉLETMÓD A FÖLDRAJZTANKÖNYVEKBEN?}

A tankönyv mint az egyik legelterjedtebb és legszélesebb körben elérhetö taneszköz számos egyéb funkciója mellett - hatással lehet a komplex szemléletmód kialakulására és a természet-, valamint társadalomtudományos gondolkodás fejlesztésére. A gimnáziumi földrajzi tananyag felépítése általában követi a földrajztudomány hagyományos felosztását, a tantervek szerint 9. évfolyamon természetföldrajzi, 10. osztályban pedig társadalomföldrajzi és csekély regionális földrajzi témák kerülnek feldolgozásra, amihez a tankönyvek is igazodnak. Az alaptanterv 2020. évi módosítása nyomán bekövetkezett ismételt óraszámcsökkenésnek a gimnáziumi földrajz is áldozatul esett, aminek következtében társadalomföldrajzi témák is bekerültek a 9. évfolyamos tananyagba. Mégsem alkotnak egységes rendszert a természetföldrajzi ismeretekkel, hanem határozottan elkülönülnek azoktól. A két tudományterület tartalmainak eltérő évfolyamon történő oktatása egyfelől jónak tekinthető, hiszen a tanulók számára könnyebben áttekinthetővé, letisztultabbá válik a tananyag, ugyanakkor az oktatási-nevelési tevékenység egyik magasabb rendű célját, a komplex szemléletmód kialakítását és a gondolkodási készség fejlesztését tekintve az elkülönítés kifejezetten károsan hathat.

Természetesen minden témakör esetén (legyen az alapvetően természetföldrajzi vagy akár társadalom-gazdaságföldrajzi) lehet találni olyan résztémát, amely alkalmas a komplex gondolkodásmód kialakítására. Egy példát említve: úgy gondolhatjuk, hogy a Földdel mint kőzetbolygóval foglalkozó témakör az egyik leginkább természetföldrajzos szemléletü része a földrajzi tananyagnak. Azonban ebben a tananyagrészben dolgozzuk fel a földrengések témakörét is, aminek mozgatórugója ugyan a természet folyamataiban és jelenségeiben keresendő, mégis számos társadalmi vonatkozása okán kiválóan alkalmas a komplex szemléletmód fejlesztésére.

Ehhez azonban elöször azt szükséges tisztázni, hogy mikor tekintünk komplexnek egy tananyagrészt, tankönyvi leckét vagy feladatot. Akkor nevezzük komplexnek, ha egyaránt van természetföldrajzi és társadalomföldrajzi vonatkozása, és a tankönyv metodikai 
eszköztára képes segíteni az ezek közötti kapcsolat megteremtését, vagyis lehetőséget ad a két terület összekapcsolására, összefüggéseik megértésére, rendszerben való kezelésére.

Vizsgálatunk fókuszában a 2020-as Nemzeti alaptanterv alapján az újgenerációs 9. és részben 10. osztályos tankönyvek átdolgozásával készült 9. évfolyamos földrajztankönyv a Védőernyőnk, a légkör címü fejezete áll (ARDAY I. et al. 2020. pp. 46-70.). Azért erre a fejezetre esett a választásunk, mert szerteágazó, sokféle nézőpontból körüljárható, számos lehetőséget nyújthat a természet- és a társadalomtudományos gondolkodás együttes fejlesztésére. A 21 oldalas tankönyvi fejezet kilenc, egyenként kétoldalas leckére tagolódik, felépítése követi a tantervi tartalmakat és a korábbi tankönyvek felépítését. Ennek megfelelően sorra veszi a légkör alkotóit és szerkezetét, a levegő felmelegedésének folyamatát, a légnyomás, a szél és a csapadékképződés témakörét, a nagy földi légkörzést, továbbá foglalkozik a ciklonokkal és az anticiklonokkal, az időjárási frontokkal. A légköri megfigyelések és érdekességek külön leckében kaptak helyet, végül pedig összefoglalás zárja a fejezetet. A fejezet feladatait a komplex szemléletmód és gondolkodásfejlesztés szempontjából tekintettük át. Az volt az elözetes feltevésünk, hogy a tankönyvben található feladatok közvetlenül kevéssé járulnak hozzá a komplex gondolkodás fejlesztéséhez, de jó alapot nyújtanak hozzá.

A tankönyvi fejezetben szereplö feladatok komplexitásának vizsgálatakor az volt a fö szempontunk, hogy megtalálhatók-e bennük egyszerre természet- és társadalomföldrajzi ismeretek, valamint, ha igen, lehetőséget nyújtanak-e azok gondolati és képzeti összekapcsolására. Ezek alapján a feladatokat három kategóriába soroltuk. Az első csoportba azok a feladatok tartoznak, amik nem tartalmaznak komplex szemléletre utaló elemet, csak természetföldrajzi információkat dolgoznak fel és természetföldrajzi gondolkodást igényelnek. A második csoportba soroltuk azokat, amelyekben természet- és társadalomföldrajzi információk egyaránt találhatók, azonban a feladat nem segíti a közöttük való kapcsolatteremtést. A harmadik csoportban van törekvés a komplex szemléletmód kialakítására, sőt, egyes feladatok kifejezetten kérik, hogy a tanulók kapcsolják össze a természetföldrajzi és a társadalomföldrajzi információkat. Minden témakör tartalmaz olyan feladatokat, amelyek irányítják a tananyag elsajátítását, segítik az elmélyítését, ezeket színes háttér jelöli. Ezen kívül a leckék végén ellenőrző funkciót betöltő összefoglaló kérdések és feladatok találhatók. Egy-egy feladat több részfeladatból áll, amelyek típusa sok esetben különböző, így azokat külön-külön kategorizáljuk (2. táblázat).

$\mathrm{Az}$ 1. kategóriába tehát olyan feladatok kerültek, melyek csak természetföldrajzi tartalmat közvetítenek, nincs társadalomföldrajzi tartalmuk. Erre példa a Légkör alkotói és szerkezete című tananyagrész 1. feladata. „a) Fogalmazd meg a légköri levegö anyagainak felépítését az x. ábra alapján! b) Sorold be azokat mennyiségük tartóssága alapján! c) Miért nem azonos a gázok tartóssága a légkörben?" (ARDAY I. et al. 2020. p. 46.). Látható, 


\begin{tabular}{|c|c|c|c|c|c|}
\hline \multirow{5}{*}{ A lecke címe } & \multirow{5}{*}{ Feladatok típusa } & \multirow{2}{*}{ Elemek megjelenése } & \multicolumn{3}{|c|}{ Komplexitás } \\
\hline & & & $\begin{array}{l}\text { 1. kate- } \\
\text { gória }\end{array}$ & $\begin{array}{l}\text { 2. kate- } \\
\text { gória }\end{array}$ & $\begin{array}{l}\text { 3. kate- } \\
\text { gória }\end{array}$ \\
\hline & & Természetföldrajzos elem & van & van & van \\
\hline & & Társadalomföldrajzos elem & nincs & van & van \\
\hline & & Kapcsolatteremtés & nincs & nincs & van \\
\hline \multirow{2}{*}{$\begin{array}{l}\text { A légkör } \\
\text { alkotói és } \\
\text { szerkezete }\end{array}$} & segítő kérdések, feladatok (21) & & 18 & 1 & 2 \\
\hline & ellenőrző kérdések, feladatok (3) & & 2 & 1 & 0 \\
\hline \multirow{2}{*}{$\begin{array}{l}\text { A levegő } \\
\text { felmelegedése }\end{array}$} & segítő kérdések, feladatok (19) & & 17 & 2 & 0 \\
\hline & ellenőrző kérdések, feladatok (3) & & 2 & 1 & 0 \\
\hline \multirow{2}{*}{$\begin{array}{l}\text { A légnyomás } \\
\text { és szél }\end{array}$} & segítő kérdések, feladatok (17) & & 14 & 1 & 2 \\
\hline & ellenőrző kérdések, feladatok (3) & & 1 & 1 & 1 \\
\hline \multirow{2}{*}{$\begin{array}{l}\text { A csapadék- } \\
\text { képződés }\end{array}$} & segítő kérdések, feladatok (33) & & 30 & 1 & 2 \\
\hline & ellenőrző kérdések, feladatok (3) & & 2 & 1 & 0 \\
\hline \multirow{2}{*}{$\begin{array}{l}\text { A nagy földi } \\
\text { légkörzés }\end{array}$} & segítő kérdések, feladatok (17) & & 15 & 0 & 2 \\
\hline & ellenőrző kérdések, feladatok (2) & & 2 & 0 & 0 \\
\hline \multirow{2}{*}{$\begin{array}{l}\text { Ciklonok, } \\
\text { anticiklonok, } \\
\text { trópusi } \\
\text { ciklonok }\end{array}$} & segítő kérdések, feladatok (10) & & 9 & 1 & 0 \\
\hline & ellenőrző kérdések, feladatok (3) & & 1 & 0 & 2 \\
\hline \multirow{2}{*}{$\begin{array}{l}\text { Időjárási } \\
\text { frontok }\end{array}$} & segítő kérdések, feladatok (18) & & 14 & 2 & 2 \\
\hline & ellenőrző kérdések, feladatok (2) & & 0 & 0 & 2 \\
\hline \multirow{2}{*}{$\begin{array}{l}\text { Légköri } \\
\text { megfigyelések } \\
\text { Érdekességek } \\
\text { a légkör föld- } \\
\text { rajzából }\end{array}$} & segítő kérdések, feladatok (10) & & 5 & 4 & 1 \\
\hline & ellenörző kérdések, feladatok & & - & - & - \\
\hline Összefoglalás & $\begin{array}{l}\text { ellenörző kérdések, feladatok } \\
\text { (39) }\end{array}$ & & 22 & 7 & 10 \\
\hline Összesen & & & 154 & 23 & 26 \\
\hline
\end{tabular}

2. táblázat. A Földrajz 9. tankönyv légkör földrajzát feldolgozó fejezete feladatainak kategorizálása (szerk. Darabos K. - Gerlang V.)

hogy a feladat a) és b) részének a célja egyszerủen az, hogy visszakérdezze, elmélyítse a tanult természetföldrajzi információkat. Ezzel szemben az összefoglalás 13. feladata már inkább alkalmas a komplex gondolkodás fejlesztésére. „Magyarázd el a leírás alapján, hogy miért alakult ki a 2013. júniusi dunai árvíz! Ábrázold Európa kontúrtérképén az időjárási helyzetet!" (ARDAY I. et al. 2020. p. 67.). Ebben a feladatban a szemelvény alapján az előzetes tudás és az információk segítségével társadalomföldrajzi és természetföldrajzi tudást is kell használniuk a tanulóknak, azonban a feladat nem utasít konkrétan az 
összefüggések feltárására, így ugyan alkalmas lehet együttes fejlesztésre, de nem tekinthető komplexnek. A harmadik kategóriába olyan feladatokat soroltunk, amelyek egyaránt igénylik természet- és társadalomföldrajzi ismeretek felhasználását, és ezen felül azok összefüggésére is rávilágítanak. Erre példa az összefoglaló fejezet 18. feladata: „Mi a teendö a képeken látható veszély elött és közben?".

Az egyes leckékben található feladatok vizsgálatakor vegyes képet kapunk azok komplexitásáról. Többségükről elmondható, hogy ugyan tartalmaznak komplex feladatot, azonban ezek aránya az összes feladathoz képest igen csekély. Vannak olyan leckék, amelyekben egyáltalán nem találunk komplex gondolkodásra irányuló feladatot, ilyen például A levegő felmelegedése. Ugyanakkor van olyan is, ahol kifejezetten sok a természet- és társadalomtudományos gondolkodást egyaránt fejlesztö tevékenység, például az Összefoglalás leckében. Az eltérések elsősorban a feldolgozott témák tartalmi különbségeire vezethetők vissza. Vannak tartalmak, amelyek kevésbé alkalmasak a komplex fejlesztésre, hiszen a céljuk alapvetően egy adott légköri folyamat leírása, megismertetése a tanulókkal, a lényeges információk közvetítése. Azonban még ezekben a leckékben is található a második kategóriába tartozó feladat, ami arra enged következtetni, hogy még ez esetben is van lehetőség a kétfajta gondolkodás együttes fejlesztésére. Az Összefoglalás lecke tartalmazza a legtöbb komplex szemléletü feladatot. Ez nyilvánvaló, hiszen az összefoglalás didaktikailag fontos feladata, hogy az addig tanult ismereteket szintetizálja, új összefüggésekbe helyezze.

\section{TANKÖNYVI FELADAT- ÉS SZÖVEGPÉLDÁK A GONDOLKODÁS FEJLESZTÉSÉRE}

A légkör földrajzáról szóló tankönyvi fejezet komplex fejlesztési lehetőségeinek megismerése érdekében minden korábban részletezett kategóriából két-két feladatot elemzünk, valamint a szöveges részeket is áttekintjük.

A Légkör alkotói és szerkezete címü első lecke 18 első kategóriába tartozó feladatot tartalmaz, a második kategóriába mindösszesen egyet, a harmadikba pedig kettőt soroltunk. A 6. feladat az első kategóriát képviseli, hat részfeladatának mindegyike csak természetföldrajzi ismeretekkel kapcsolatos és természetföldrajzi gondolkodást igényel, ezek a következők: „a) Hogyan változnak a légkör fizikai tulajdonságai a felszíntöl távolodva? b) Keress összefüggést az egyes fizikai tulajdonságok változásai között! c) Milyen kapcsolatokat találsz a hömérséklet-változás és a légkör rétegeinek határvonalai között? d) Melyik rétegben található a légkör tömegének túlnyomó többsége? e) Hányszorosa a sztratoszféra vastagsága a troposzféra vastagságának? f) Hogyan változik a levegö összetétele a két alsó szférában?" (ARDAY I. et al. 2020. p. 47.). A részfeladatok egyikében sincs szükség társadalomföldrajzi tartalmak felidézésére, alkalmazására, így értelemszerüen 
azok összekapcsolása sem történik meg a természetföldrajzi ismeretekkel. Hasonló jellegü A csapadékképződés címü lecke 1. feladata: „Sorolj fel csapadékfajtákat! Melyik csapadék milyen körülmények között keletkezik?” (ARDAY I. et al. 2020. p. 52.). Ebben a feladatban sincs társadalomföldrajzos utalás, csupán korábban elsajátított természetföldrajzi ismeretek felidézése, a fogalmak fő jellemzőik alapján történő elkülönítése és rendszerezése szükséges a megoldáshoz.

A második kategóriába természet- és társadalomföldrajzi ismereteket egyaránt igénylő feladatokat soroltunk, amelyek mindkét gondolkodásmódot fejleszthetik, mégsem teremtenek kapcsolatot a tudományterületek között. Erre példa $A$ nagy földi légkörzés címü lecke 8. feladata. „Készíts útvonaltervet a Global Challenge Föld körüli vitorlásverseny indulóinak! A minden kontinenst érintő verseny kikötői ellenőrző állomásait úgy helyezd el, hogy a leggyorsabban megközelíthetők legyenek a vitorlások számára!" (ARDAY I. et al. 2020. p. 57.). A feladat megoldása természet- és társadalomföldrajzos ismeretszerzést egyaránt igényel, hiszen egy vitorlásverseny útvonalát kell megtervezni az összes kontinens érintésével. Arra vonatkozó utasítás azonban nincs, hogy indoklás is szükséges, vagyis azt nem kell megfogalmazniuk a tanulóknak, hogy miért úgy tervezték meg az utat. A tervezéskor többek között azt is figyelembe kell venniük a tanulóknak, hogy a Global Challenge egy nagyjából tíz hónapig tartó verseny, ahol a hajók általában keletről nyugatra vitorlázzák körül Antarktikát, és a hosszabb távok után a versenyzők akár egy-két hetet is pihennek a tovább indulás elött. Tehát a megoldáshoz természet- és társadalomföldrajzi ismeretek egyaránt szükségesek, azonban nincs konkrét instrukció az összekapcsolásukra. A feladat a gondolkodási jellemzők alapján is kettős. Egyrészről megjelenik benne a természetföldrajzra jellemző, meghatározott szempontrendszerek alapján történő gondolkodás (például a kontinensek közötti legrövidebb út megtalálása), miközben a feladat célja a gondolkodási folyamat végigjárása (hiszen ahhoz, hogy a tanuló megtervezze az útvonalat, végig kell gondolnia az azt befolyásoló tényezőket, például a tengeráramlásokat, a légköri viszonyokat), ami pedig a társadalomföldrajzi gondolkodás egyik tipikus vonása. A második kategóriába sorolható A légkör alkotói és szerkezete című tankönyvi lecke 7. feladatának a) része is: „Mi a szerepe a sztratoszféra ózonrétegének?” (ARDAY I. et al. 2020. p. 47.). Tartalmazza a természet- és a társadalomföldrajzi ismereteket, feltételezi a kétfajta gondolkodás alkalmazását is, azonban komplex szemléletmódot nem igényel A feladat rákérdez az ózonréteg szerepére, utal rá, hogy az ember számára fontos, azonban nem kéri, hogy a természetföldrajzi tények, folyamatok, összefüggések és azok emberiségre gyakorolt hatása között párhuzamot húzzon a tanuló. A kétfajta gondolkodás nem jelenik meg komplexen, mivel a feladat nem ad konkrét utasítást arra, hogy a természet- és társadalomföldrajzos ismereteket együtt, szintetizálva alkalmazzák a tanulók a megoldás során. 
A harmadik kategóriába azok a feladatok kerültek, amelyek esetén a természet- és társadalomföldrajzos ismeretek összekapcsolása megtörténik azáltal, hogy a feladat vagy konkrét utasítást ad erre vagy olyan problémafeladatnak tekinthető, amely mindkét gondolkodásmódot egyaránt igényli, tehát a kettő együttes fejlesztésére alkalmas. Ezek alapján komplexnek tekinthető A légkör alkotói és szerkezete címü lecke 3. feladata: „Olvasd le az x. ábráról, hogy mely tevékenységek járulnak hozzá a légkör anyagi összetételének változásához!” (ArDAy I. et al. 2020. p. 46.). A feladat megoldása során szükséges a természetföldrajza jellemző rész-egész kapcsolatok értelmezése és a társadalomföldrajzi gondolkodásra jellemző hálózatokban való gondolkodás is, ráadásul a tanulónak szintetizálnia kell a két tudományterület ismeretanyagát. A légnyomás és a szél címü lecke 7. d) feladata szintén komplex, ami csak az előtte lévő, a tengerparti szélrendszer kialakulásáról, annak jellegzetességeiről szóló részfeladatokkal együtt értelmezhető, amik az első kategóriába tartoznak: „Hogyan befolyásolja a tengerparton élők életét ez a szélrendszer?” (ArdAY I. et al. 2020. p. 51.) Ez a feladatrész azért tekinthető komplexnek, mert igényli az ok-okozati összefüggések meglátását, ami a természettudományos gondolkodás egyik jellemzője, hiszen be kell mutatni, hogy a szélrendszer milyen csapadék- és hőmérsékleti viszonyokat okoz a tengerpartokon. Ezen felül a társadalom szempontja is szerepet kap, hiszen konkrétan a tengerparti lakosság életére kiható következményekre kérdez rá.

Annakérdekében, hogy komplexebb képet kapjunkarról, mennyire alkalmas a témakör a természet- és társadalomföldrajzos gondolkodás komplex fejlesztésére, megvizsgáltuk a Védöernyőnk, a légkör tankönyvi fejezet szöveges, leíró részeit is. A törzsszövegek tanulmányozásakor ugyanazt a kettősséget tapasztalhatjuk komplexitás szempontjából, mint a feladatok esetében. Egyes leckékben egyáltalán nincs komplex gondolkodást igénylö szöveg. Erre példa A nagy földi légkörzés és A levegö felmelegedése, ahol csak alapvető természetföldrajzi információk átadására, összegzésére törekednek. Azonban vannak olyanok is, amelyek társadalomföldrajzi ismereteket is kínálnak, vagy össze is kapcsolják azokat a természetföldrajzi információkkal. Ilyen A légnyomás és a szél, aminek törzszszövege ugyan alig tartalmaz komplex ismereteket, azonban a zöld kerettel jelölt kiegészítő információk annál inkább. Ugyanez látható A csapadékképződés című lecke esetén is, ahol a törzsszövegben csak természetföldrajzos információk vannak, de ezen felül ebben a témakörben is helyet kapnak kiegészítő szövegek, amelyekben egy teljes oldalon keresztül részletezik a veszélyes időjárási jelenségeket, figyelembe véve azok társadalomföldrajzi megközelítéseit is, lehetővé téve a komplex szemléletmód kialakítását.

Látható tehát, hogy az általunk vizsgált Védőernyőnk, a légkör tankönyvi fejezetben található ugyan komplex szemléletü szöveg vagy feladat, de arányuk a teljes leckéhez képest elenyésző. Természetesen a tankönyv csak a tanulási-tanítási folyamat egy segédeszköze, nem kizárólag azon múlik, hogy egy-egy földrajzórán mennyire valósul meg a 
természet- és társadalomtudományos gondolkodás együttes, komplex fejlesztése, de jó alapot nyújthat, ami tanári irányítással és kreativitással kiegészítve hatékonnyá válhat.

\section{KÖVETKEZTETÉSEK}

A tankönyv vizsgálata során az volt az alapvető feltevésünk, hogy valószínűleg a földrajz kettőssége miatt nem fogunk túl sok a gondolkodást komplexen fejlesztő feladatot találni. Vizsgálatunk, a Védöernyőnk, a légkör fejezet feldolgozása ezt igazolta is. A 3. ábra a teljes fejezetben található összes feladat besorolását mutatja. Mint ahogy az a diagramról is leolvasható, a feladatok túlnyomó többsége (76\%) az első csoportba sorolható, vagyis a természetföldrajzi ismeretekre vonatkozik. A feladatok 11\%-a ugyan tartalmaz mind természet-, mind társadalomföldrajzi tényeket, megállapításokat, azonban nem kéri a tanulóktól ezek összekapcsolását. A feladatoknak csupán 13\%-áról mondhatjuk, hogy valóban komplex szemléletű, azaz az utasítás nemcsak a különböző tények visszaidézését szolgálja, hanem a földrajz két területe közötti összefüggések megtalálására, belátására is rávezeti a tanulót. Összességében tehát azt mondhatjuk, hogy vannak ugyan komplex feladatok a fejezetben, azonban ezek csak töredékét adják az összes feladatnak.

\section{ÖSSZEFOGLALÁS}

Láthattuk tehát, hogy a gondolkodás és annak fejlesztése egy igen kiterjedt témakör, amivel a történelem során rengetegen foglalkoztak már. A 20. században három egymást követő irányzat határozta meg a gondolkodásfejlesztést, az első a pszichometria volt, amelyet a Piaget-iskola és a kognitív pszichológia követett. Ezen irányzatok ugyan eltérően értelmezték a gondolkodást, más és más kutatásmódszertant alkalmaztak, de mindegyik irányzat eredményei fontosak voltak mai felfogásunk kialakulásához. A gondolkodás és gondolkodásfejlesztés alapvetően a pszichológia kutatási területe, de szaktanárként tisztában

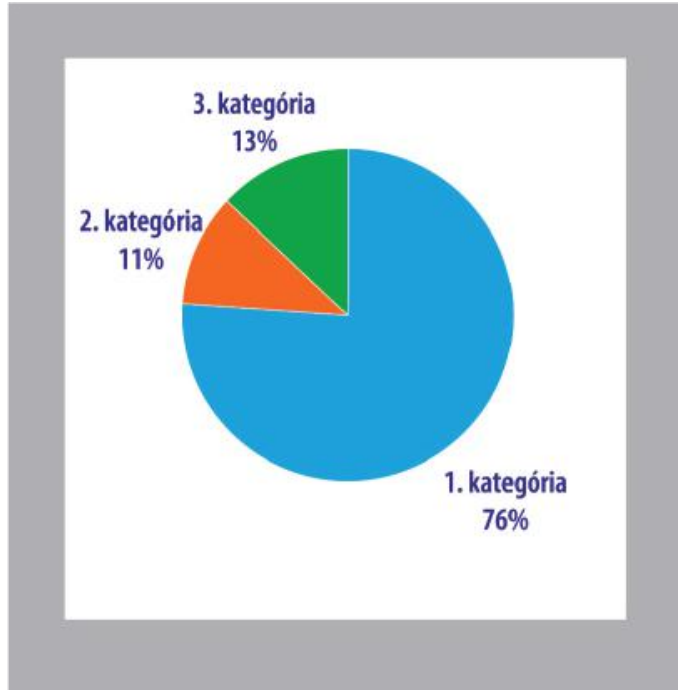

3. ábra. A 9. osztályos földrajztankönyv Védöernyőnk, a légkör címü fejezete feladatainak kategorizálása gondolkodási szempontból (szerk. Darabos K. - Gerlang V.) 
kell lennünk az alapjaival a megfelelő fejlesztés érdekében, és különösen fontos tudnunk, hogy ez tárgyanként eltérő. A földrajztudomány a természet- és társadalomtudományok szintetizálása, így a földrajz tantárgy természet- és társadalomtudományos gondolkodást is igényel. Tanulmányunkban ezek komplex fejlesztését vizsgáltuk a legfrissebb 9. évfolyamos földrajztankönyv egy olyan témakörében (a légkör földrajza), amely tartalmából adódóan kiválóan alkalmas lehet a két tudományterülettel kapcsolatos gondolkodásmód együttes fejlesztésére. Azt tapasztaltuk, hogy a feladatoknak csak kis százaléka tekinthető komplexnek, annak ellenére, hogy ez az egyik legösszetettebb témakör, tekintve, hogy a természetföldrajzi jelenségek mindegyikének van társadalmi hatása is. Ebből adódóan kiválóan alkalmas lenne a komplex szemléletmód fejlesztésére, ez mégsem jellemző.

Természetesen a természet- és a társadalomtudományos gondolkodás együttes fejlesztésére olyankor is van lehetőség, amikor a tankönyvi feladatok egyértelmüen nem térnek ki rá, hiszen a földrajz tantárgy egyik sajátossága az összetettség. Minden mindennel összefügg, bármilyen természetföldrajzi témáról is beszéljünk, annak van társadalomföldrajzi vonatkozása és fordítva. Így a legtöbb, első kategóriába sorolt feladatban ott rejlik a lehetőség arra, hogy komplex, gondolkodásfejlesztő tevékenységgé váljon a tanár irányításával. Ennek segítségével könnyebben elérhetö a földrajztanítás egyik célja is, hogy olyan tanulók kerüljenek ki az iskolából, akik képesek világunkat rendszerként szemlélni, amihez elengedhetetlen, hogy lássák az összefüggéseket a természet- és társadalomföldrajzi tények között, és feltáruljanak előttük a kétféle gondolkodásmód különbségei.

\section{IRODALOM}

Anderson, L. W. - Krathwohl, D. R. (szerk.) (2001): A taxonomy for learning, teaching and assessing. A revision of Bloom's taxonomy of educational objectives. - Allyn \& Bacon, Boston. 332 p.

Arday I. et al. (2020): Földrajz 9. tankönyv. - Oktatási Hivatal, Budapest. 161 p.

Baron, J. (1988): Thinking and deciding. - Cambridge University Press, Cambridge. 528 p.

Bühner, M. - Kröner, S. - Ziegler, M. (2008): Working memory, visual-spatial-intelligence and their relationship to problem-solving. - Intelligence 36. 6. pp. 672-680. https://doi.org/10.1016/j. intell.2008.03.008

CsApó B. (2003): A képességek fejlődése és iskolai fejlesztése. - Akadémiai Kiadó, Budapest. 284 p.

Inhelder, B. - Piaget, J. (1967): A gyermek logikájától az ifjú logikájáig. - Akadémiai Kiadó, Budapest. $335 \mathrm{p}$.

Inhelder, B. - Piaget, J. (1999): Gyermeklélektan. - Osiris Kiadó, Budapest. pp. 26-29.

Kunn, T. S. (2000): A tudományos forradalmak szerkezete. - Osiris Kiadó, Budapest. 261 p.

Livingstone, D. N. (1992): The geographical tradition: episodes in the history of a contested enterprise. Wiley-Blackwell, Oxford. 444 p. 
Livingstone, D. N. (2009): History of geography. - In: Gregory, D. - Johnston, R. - Pratt, G. - Watts, M. Whatmore, S. (szerk.): Dictionary of human geography. - Blackwell, Oxford. pp. 295-299.

MAKÁDI M. (2015): Tevékenykedtető módszerek a földrajztanításban. - Eötvös Loránd Tudományegyetem TTK FFI, Budapest. 183 p.

NAGY J. (2003): A rendszerező képesség fejlődésének kritériumorientált feltárása. - Magyar Pedagógia 103. 3. pp. 269-314.

NÁdAsi A. (2014): Az oktatásszervezés és -technológia aktuális kérdései és trendjei. - Eszterházy Károly Főiskola, Eger. Digitális tankönyvtár. https://regi.tankonyvtar.hu/hu/tartalom/ tamop412A/2011-0021_24_az_oktatastervezes_es_technologia_aktualis_kerdesei_es_trendjei/ index.html (utolsó letöltés: 2020. 11. 05.)

Piaget, J. (1993): Az értelem pszichológiája. - Gondolat Kiadó, Budapest. 259 p.

Probáld F. (1999): A földrajz fejlődése a XX. század második felében. - In: MENDÖL T. (szerk.): A földrajztudomány története az ókortól napjainkig. ELTE Eötvös Kiadó, Budapest. pp. 224-257.

Rózsa S. - Hevesi K. (2006): A pszichológiai mérés történeti gyökerei és a mérés problémája a pszichológiában. - In: Rózsa S. - Nagybányai Nagy O. - Oláh A. (szerk.) 2006: A pszichológiai mérés alapjai - Elmélet, módszer és gyakorlati alkalmazás. Bölcsész Konzorcium, Budapest. pp. 5-25.

Shapin, S. (1998): Placing the view from nowhere: historical and sociological problems in the location of science. - Transactions of the Institute of British Geographers 23. 1. pp. 5-12. https://doi. org/10.1111/j.0020-2754.1998.00005.x

VILEs, H. (2005): A divided discipline? - In: Castree, N. - Rogers, A. - Sherman, D.: Questioning geography - fundamental debates. Blackwell Publishing, Malden. pp. 26-39.

Wason, P. C. (1968): Reasoning about a rule. - The Quarterly Journal of Experimental Psychology 20. 3. pp. 273-281. https://doi.org/10.1080/14640746808400161 